\title{
Chronic Environmental or Genetic Elevation of Galanin in Noradrenergic Neurons Confers Stress Resilience in Mice
}

\author{
Rachel P. Tillage, ${ }^{1}$ Genevieve E. Wilson, ${ }^{1}$ L. Cameron Liles, ${ }^{1}$ Philip V. Holmes, ${ }^{2}$ and David Weinshenker ${ }^{1}$ \\ ${ }^{1}$ Department of Human Genetics, Emory University School of Medicine, Atlanta, Georgia 30322, and ${ }^{2}$ Department of Psychology, University of \\ Georgia, Athens, Georgia 30602
}

The neuropeptide galanin has been implicated in stress-related neuropsychiatric disorders in humans and rodent models. While pharmacological treatments for these disorders are ineffective for many individuals, physical activity is beneficial for stress-related symptoms. Galanin is highly expressed in the noradrenergic system, particularly the locus coeruleus (LC), which is dysregulated in stress-related disorders and activated by exercise. Galanin expression is elevated in the LC by chronic exercise, and blockade of galanin transmission attenuates exercise-induced stress resilience. However, most research on this topic has been done in rats, so it is unclear whether the relationship between exercise and galanin is species specific. Moreover, use of intracerebroventricular (ICV) galanin receptor antagonists in prior studies precluded defining a causal role for LCderived galanin specifically. Therefore, the goals of this study were twofold. First, we investigated whether physical activity (chronic wheel running) increases stress resilience and galanin expression in the LC of male and female mice. Next, we used transgenic mice that overexpress galanin in noradrenergic neurons (Gal OX) to determine how chronically elevated noradrenergic-derived galanin, alone, alters anxiogenic-like responses to stress. We found that three weeks of ad libitum access to a running wheel in their home cage increased galanin mRNA in the LC of mice, which was correlated with and conferred resilience to stress. The effects of exercise were phenocopied by galanin overexpression in noradrenergic neurons, and Gal OX mice were resistant to the anxiogenic effect of optogenetic LC activation. These findings support a role for chronically increased noradrenergic galanin in mediating resilience to stress.

Key words: anxiety; exercise; galanin; locus coeruleus; mice; stress

Significance Statement

Understanding the neurobiological mechanisms underlying behavioral responses to stress is necessary to improve treatments for stress-related neuropsychiatric disorders. Increased physical activity is associated with stress resilience in humans, but the neurobiological mechanisms underlying this effect are not clear. Here, we investigate a potential causal mechanism of this effect driven by the neuropeptide galanin from the main noradrenergic nucleus, the locus coeruleus (LC). We show that chronic voluntary wheel running in mice increases stress resilience and increases galanin expression in the LC. Furthermore, we show that genetic overexpression of galanin in noradrenergic neurons causes resilience to a stressor and the anxiogenic effects of optogenetic LC activation. These findings support a role for chronically increased noradrenergic galanin in mediating resilience to stress.

\section{Introduction}

Stress-related neuropsychiatric disorders affect $\sim 600$ million people worldwide, yet current pharmacological treatments have

Received Apr. 24, 2020; revised June 16, 2020; accepted July 14, 2020.

Author contributions: R.P.T., P.V.H., and D.W. designed research; R.P.T., G.E.W., and L.C.L. performed research; R.P.T. and G.E.W. analyzed data; R.P.T. and D.W. wrote the paper.

This work was supported by the National Institutes of Health Extramural Research Program Grants MH116622 (to R.P.T.) and DA038453, AG047667, AG061175, and NS102306 (to D.W.). We thank Jason Schroeder for his assistance with the behavioral experiments, John Hepler and Suneela Ramineni for assistance with the in situ hybridization experiment, and Cheryl Strauss for helpful editing of the manuscript.

The authors declare no competing financial interests.

Correspondence should be addressed to David Weinshenker at dweinsh@emory.edu.

https://doi.org/10.1523/JNEUROSCI.0973-20.2020

Copyright $(2020$ the authors limited efficacy and cause adverse side effects for many people (Nestler et al., 2002; Rush et al., 2006; James et al., 2018). Clinical studies have consistently linked physical exercise to improvements in a wide array of neuropsychiatric disorders (Herring et al., 2010; Cooney et al., 2013; Ashdown-Franks et al., 2020). Individuals who regularly exercise are less likely to experience stress-related neuropsychiatric disorders, such as depression, anxiety, and posttraumatic stress disorder (Whitworth and Ciccolo, 2016; Chekroud et al., 2018; Harvey et al., 2018), and chronic voluntary wheel running increases resilience to various stressors in rodents (Sciolino et al., 2012; Kingston et al., 2018; Mul et al., 2018; Tanner et al., 2019). A multitude of biological changes occur as a result of chronically increased physical activity which may or may not be causally linked to alterations in 
stress resilience and mood; however, a promising candidate for mediating these beneficial effects is the neuropeptide galanin.

Galanin is abundant in the brain (Tatemoto et al., 1983; Kofler et al., 2004; Fang et al., 2015), and modulates stress, mood, cognition, food intake, nociception, and seizures (Mitsukawa et al., 2008; Lang et al., 2015). Human studies have implicated genetic variants in the genes encoding the galanin gene and its receptors (GalR1, GalR2, and GalR3) in conferring an increased risk of depression and anxiety, especially in the context of environmental stress exposure, and postmortem studies have similarly revealed galaninergic dysregulation in people with major depressive disorder (Barde et al., 2016).

While the pattern of galanin expression in the brain can vary from species to species, it is particularly rich in the noradrenergic locus coeruleus (LC) of both humans and rodents (Skofitsch and Jacobowitz, 1985; Melander et al., 1986; Holets et al., 1988; Chan-Palay et al., 1990; Pérez et al., 2001; Le Maître et al., 2013). The LC is activated by stress, and norepinephrine (NE) release plays a crucial role in the stress response, coordinating a host of downstream effects via broad axonal projections required for the "fight-or-flight" response (Valentino and Van Bockstaele, 2008). Consistent with this role, the LC-NE system is dysregulated in stress-related neuropsychiatric disorders, such as anxiety, depression, and posttraumatic stress disorder (Roy et al., 1988, 2017; Ordway et al., 1994; Wong et al., 2000; Bissette et al., 2003; Ehnvall et al., 2003; Naegeli et al., 2018). In rats, galanin expression increases in the LC following chronic wheel running or treadmill exercise and correlates with running distance (O'Neal et al., 2001; Van Hoomissen et al., 2004; Holmes et al., 2006; Sciolino et al., 2012, 2015; Epps et al., 2013), and in Sciolino et al. (2015), we found that wheel running confers resilience to a stressor. Galanin has both acute neuromodulatory and chronic neurotrophic properties, and the beneficial effects of exercise in rats were blocked by chronic, but not acute, intracerebroventricular (ICV) infusion of a galanin antagonist and recapitulated by chronic ICV infusion of galanin alone, suggesting a neurotrophic mechanism of action (Sciolino et al., 2015). However, it is not known whether these phenomena can be extrapolated to other species or attributed to LC-derived galanin.

To investigate the contribution of chronically elevated noradrenergic galanin to stress resilience in mice, we investigated behavioral responses to foot shock in both an environmental (voluntary wheel running) and genetic (dopamine $\beta$-hydroxylase-galanin transgene; Gal OX) model of LC galanin overexpression. To isolate anxietylike responses mediated specifically by the LC, we also examined the behavior of Gal OX mice following optogenetic LC activation. Our findings support a causal role for chronically elevated noradrenergic-derived galanin in promoting stress resilience.

\section{Materials and Methods}

Animals

All procedures related to the use of animals were approved by the Institutional Animal Care and Use Committee of Emory University and were in accordance with the National Institutes of Health guidelines for the care and use of laboratory animals. All mice were group housed and maintained on a 12/12 h light/dark cycle with access to food and water ad libitum, unless noted otherwise. All manipulations and behavioral tests occurred during the light cycle. Adult male and female mice (three to nine months), with equal numbers of both sexes, were used for all experiments. The Gal OX mice were generated with a transgene containing the mouse galanin gene driven by the human dopamine $\beta$-hydroxylase $(D b h)$ promoter, resulting in an fivefold increase in galanin mRNA in noradrenergic and adrenergic neurons and a twofold increase in galanin protein in LC-innervated forebrain regions compared with
Table 1. Antibodies used

\begin{tabular}{lllll}
\hline Antibody & Species & Dilution & Source & Catalog \# \\
\hline TH & Chicken & $1: 1000$ & Abcam & AB76442 \\
c-fos & Rabbit & $1: 5000$ & Millipore & ABE457 \\
DsRed & Rabbit & $1: 1000$ & Takara & 632496 \\
Alexa Fluor 488 anti-rabbit & Goat & $1: 500$ & Invitrogen & A-11008 \\
Alexa Fluor 568 anti-rabbit & Goat & $1: 500$ & Invitrogen & A-11011 \\
Alexa Fluor 488 anti-chicken & Goat & $1: 500$ & Abcam & AB150169 \\
Alexa Fluor 568 anti-chicken & Goat & $1: 500$ & Invitrogen & A-11041 \\
\hline
\end{tabular}

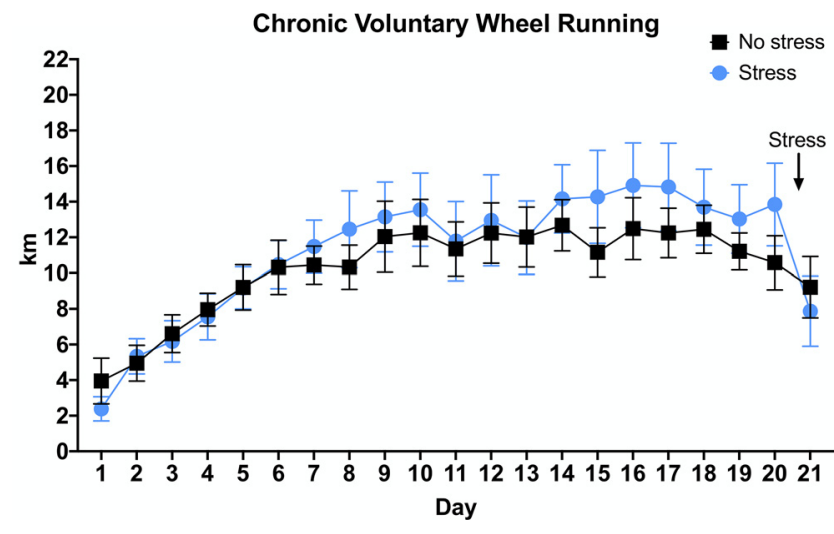

Figure 1. Distance traveled by mice with access to running wheels. WT C57BI6/J mice were given ad libitum access to running wheels in their home cage for three weeks; $n=7$ per group, mixed males and females (for breakdown by sex, see Extended Data Fig. 1-1). Error bars show SEM.

wild-type (WT) littermates (The Jackson Laboratory stock \#004996; Steiner et al., 2001). All mice used in this study were on a C57BL/6J background.

\section{Exercise}

Both exercise and sedentary mice were singly housed for one week before the start of running wheel experiments. On the first day of the experiment, low-profile wireless running wheels (Med Associates) were placed in the cage of the exercise mice. Sedentary animals had no additions to their home cages, consistent with our previous studies in rats (Sciolino et al., 2012, 2015). All mice were monitored daily for three weeks.

\section{Behavioral assays}

For the behavioral battery following exercise, assays were conducted 24$48 \mathrm{~h}$ after foot shock stress, with at least $2-3 \mathrm{~h}$ between tests, in order of least stressful to most stressful to minimize effects from the previous tests. Baseline behavioral assays [open field (OF), elevated plus maze (EPM), forced swim test (FST), fear conditioning, nestlet shredding, elevated zero maze (EZM), marble burying (MB), novelty-suppressed feeding (NSF), locomotor activity, and shock-probe defensive burying (SPDB)] were conducted as previously described (Tillage et al., 2020) with at least $4-5 \mathrm{~d}$ between tests.

\section{Stress paradigm}

The foot shock stress protocol was modified from a previously published paradigm (Lecca et al., 2016). Mice were individually exposed to $20 \mathrm{~min}$ of foot shock exposure consisting of 19 shocks randomly interspaced by 30,60 , or $90 \mathrm{~s}(0.5-\mathrm{ms}$ shocks, $1 \mathrm{~mA})$ in chambers (Coulbourn Instruments) equipped with a house light, a ceiling-mounted camera, and an electric grid shock floor. Control animals were placed in the chamber for $20 \mathrm{~min}$ but were not administered shocks. Chambers were cleaned with MB-10 between animals.

\section{Corticosterone (CORT) measurement}

Mice used for CORT measurement went through the foot shock stress paradigm described above and were anesthetized with isoflurane $15 \mathrm{~min}$ after the end of the stress. Mice were rapidly decapitated, and trunk 


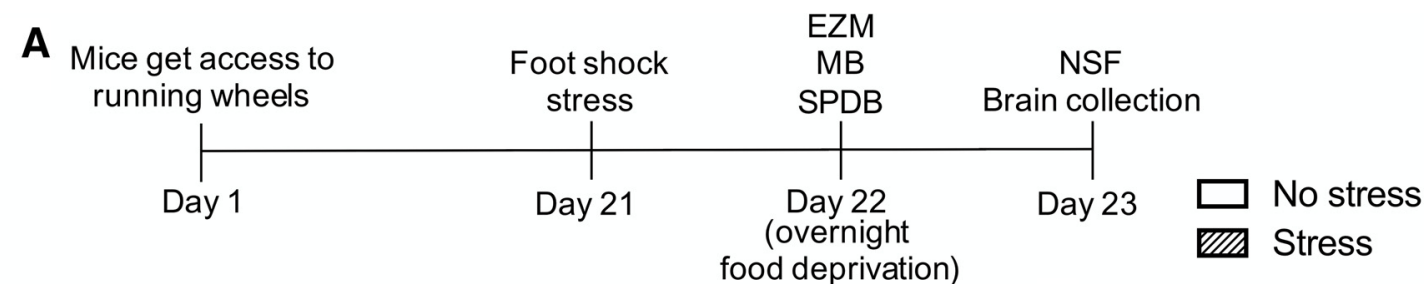

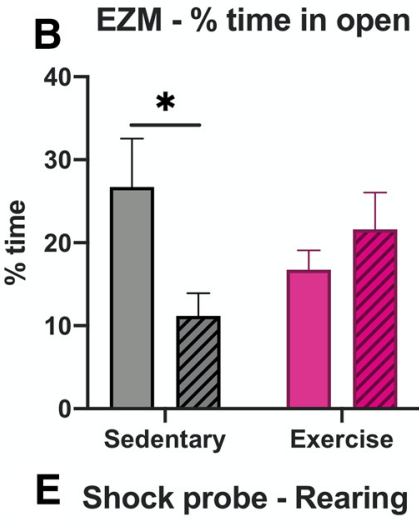

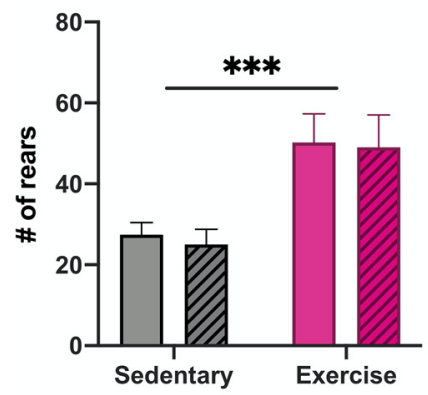

H Shock probe - Digging

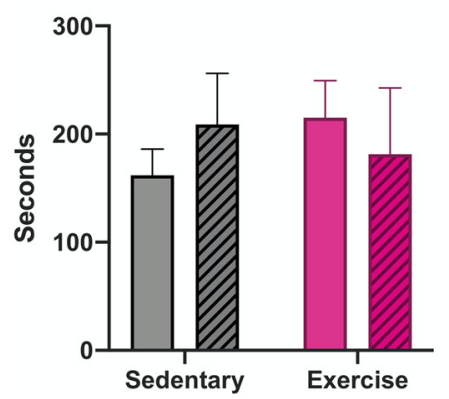

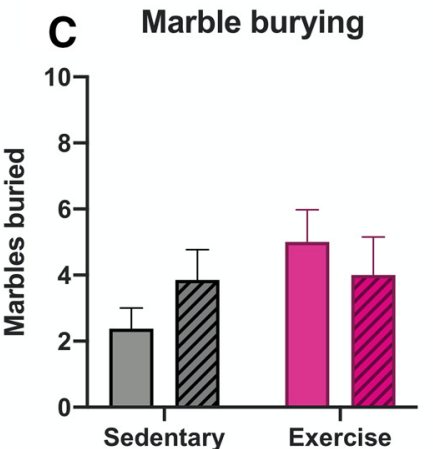

F Shock probe - Probe touches
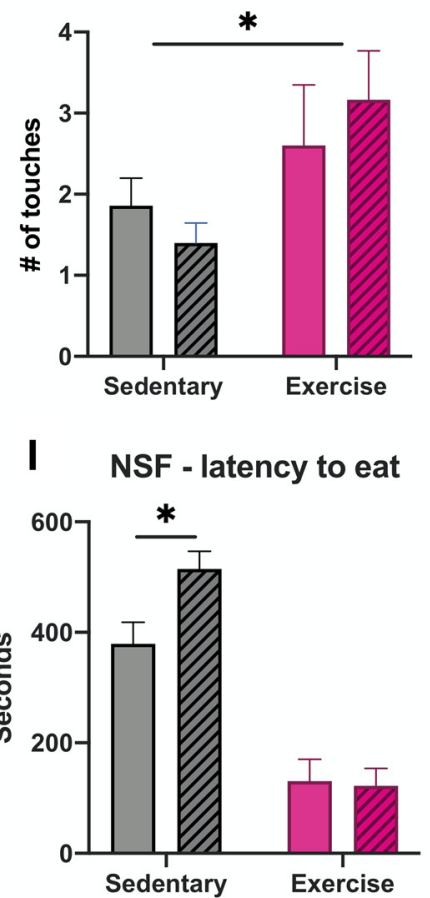

D Shock probe - Freezing

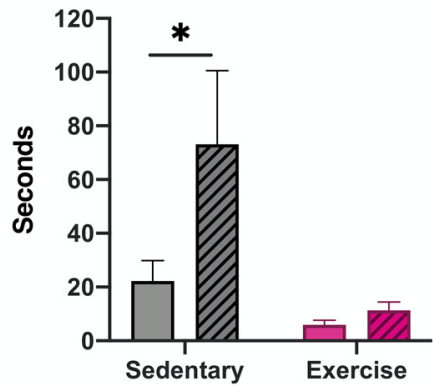

G Shock probe - Grooming

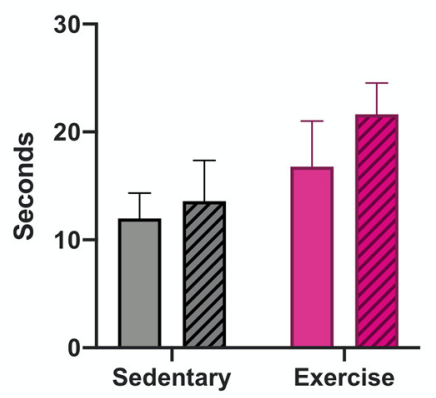

J NSF - food consumed

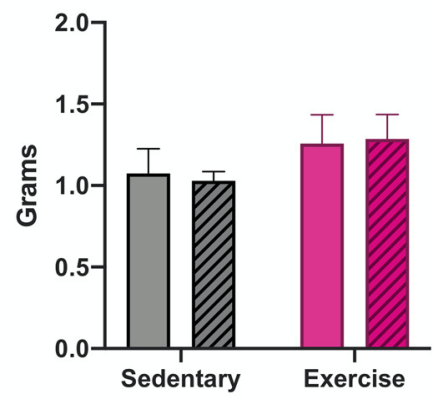

Figure 2. Exercise increases resilience to foot shock stress-induced anxiety-like behavior. WT (57B16/J mice were given ad libitum access to running wheels in their home cage ("Exercise") or no running wheel ("Sedentary") for three weeks, then were tested in behavioral assays $24-48 \mathrm{~h}$ following foot shock ("Stress") or no foot shock ("No stress"). $\boldsymbol{A}$, Exercise paradigm timeline. $\boldsymbol{B}$, Sedentary mice show decreased time spent in the open arms of the EZM after stress, but exercise mice do not. C, No significant differences were seen in the MB assay. $\boldsymbol{D}$, In the SPDB assay, sedentary stressed mice showed increased freezing compared with sedentary non-stressed mice, but there was no difference between stressed and non-stress exercise mice. Exercise mice showed an overall increase in both rearing $(\boldsymbol{E})$ and number of probe touches compared with sedentary mice $(\boldsymbol{F})$, with no effect of stress. $\boldsymbol{G}$, There were no differences as a result of exercise or stress on grooming or $(\boldsymbol{H})$ digging in the SPDB assay. $\boldsymbol{I}$, In the NSF test, sedentary mice took significantly longer to eat after stress compared with non-stressed sedentary mice, with no difference between stressed and non-stressed exercise mice. J, Exercise mice tended to consume more food during the hour after the NSF test, but it was not significant; $n=7-8$ mice per group, mixed males and females (for breakdown by sex, see Extended Data Figure 2-1). Error bars show SEM; ${ }^{*} p<0.05$, ${ }^{* * *} p<0.001$.

blood was collected in EDTA-coated tubes (Sarstedt Inc.) and chilled on ice. Blood was centrifuged for $20 \mathrm{~min}$ at $3000 \mathrm{rpm}$ at $4^{\circ} \mathrm{C}$, and the resulting plasma was collected and stored at $-80^{\circ} \mathrm{C}$. CORT was measured using the Enzo Life Sciences kit following the manufacturer's small volume protocol for blood plasma, including diluting samples 1:40 with a steroid displacement reagent solution.

Galanin in situ hybridization and densitometry

To measure galanin mRNA in the LC following exercise, mice were deeply anesthetized with isoflurane and rapidly decapitated for brain extraction. Brains were collected, flash frozen in Tissue Freezing Medium, and stored at $-80^{\circ} \mathrm{C}$ until processing. Brains were sectioned at $12 \mu \mathrm{m}$ and collected on gelatin-coated slides (SouthernBiotech). Slides were stored at $-80^{\circ} \mathrm{C}$. Galanin in situ hybridization was conducted and images were acquired as previously described (Sciolino et al., 2015). For quantification, images were converted to 16-bit in NIH ImageJ (https://imagej.nih.gov/ij/), and the mean grayscale value was measured in three to four LC sections per animal using a standardized region of interest to obtain an average measurement per animal. The mean grayscale value of the 

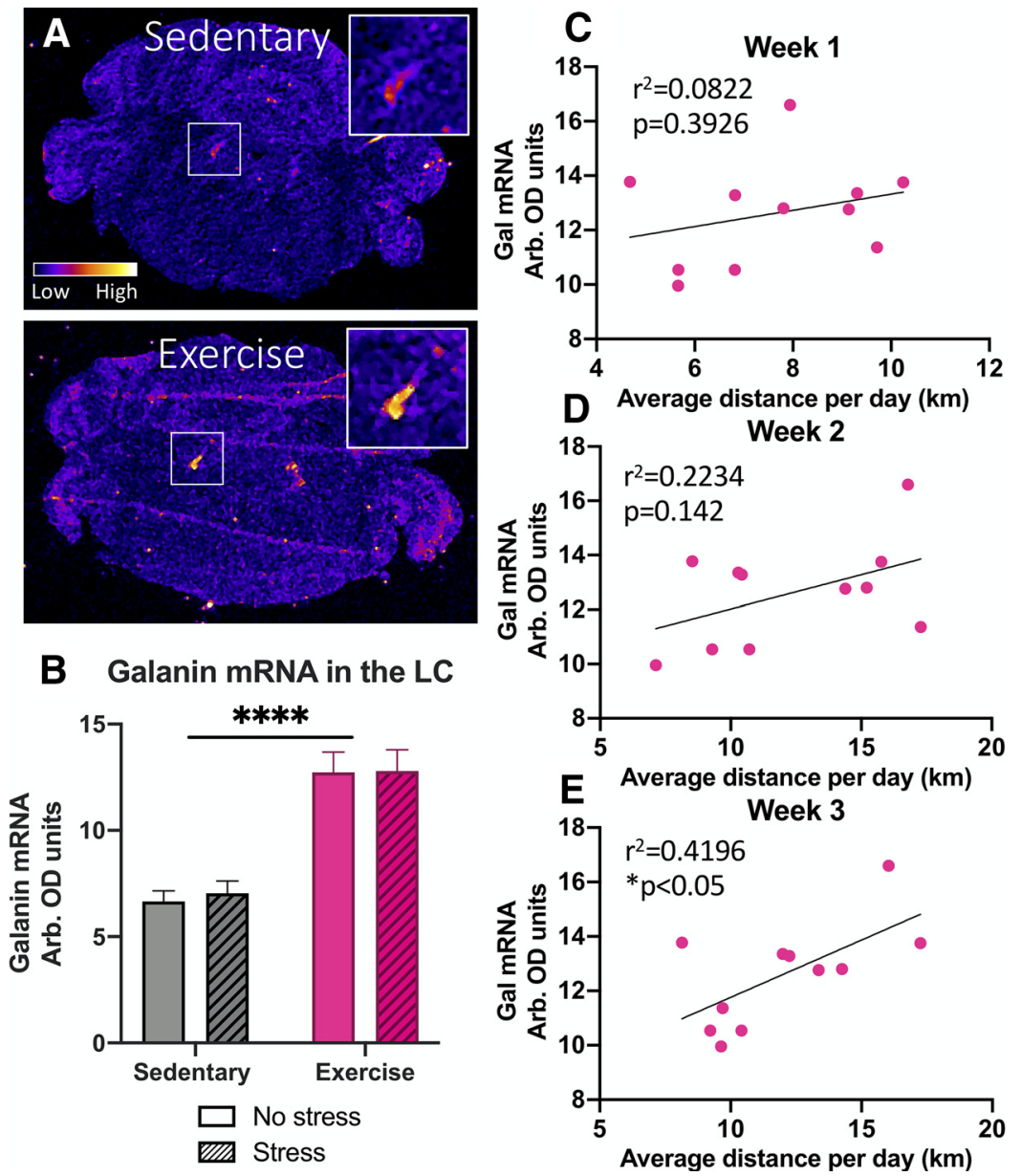

Figure 3. Exercise increases galanin mRNA in the LC of mice. Galanin mRNA levels in the LC were measured via in situ hybridization in WT C57B/6/J mice following three weeks of ad libitum access to running wheels in their home cage (Exercise) or no running wheels (Sedentary), foot shock (Stress) or no foot shock (No stress), and behavioral testing. $\boldsymbol{A}$, Representative images of galanin in situ hybridization. B, Quantitative densitometry analysis revealed that exercise mice showed significantly elevated galanin mRNA in the LC compared with sedentary mice, with no effect of foot shock stress exposure. C, Correlation analysis showed that the average distance ran per day during the third week for each mouse showed a significant positive correlation with the level of galanin mRNA expression in the LC. The average distance ran per day during the first $(\boldsymbol{D})$ and second $(\boldsymbol{E})$ weeks did not correlate with the level of galanin mRNA expression in the LC; $n=5-8$ mice per group, mixed males and females (for breakdown by sex, see Extended Data Fig. 3-1). Error bars show SEM; ${ }^{* * * *} p<0.0001$.

background was subtracted out for each measurement. The experimenter was blind to treatment during image analysis.

\section{Stereotaxic surgery}

For optogenetic experiments, mice were anesthetized with isoflurane and given the analgesic meloxicam at the start of the surgery $(5 \mathrm{mg} / \mathrm{kg}$, s.c.). A lentiviral vector containing the channel-rhodopsin-2 (ChR2) construct with an mCherry tag under control of the noradrenergic-specific PRSx8 promoter (Hwang et al., 2001) was infused unilaterally into the LC (-5.4 AP; +1.2 ML; -4.0 DV) with a $5-\mu l$ Hamilton syringe and Quintessential Stereotaxic Injector (Stoelting) pump at a rate of $0.15 \mu \mathrm{l} / \mathrm{min}$. Unilateral LC stimulation is sufficient to produce behavioral effects in mice that are indistinguishable from bilateral stimulation (Carter et al., 2010; $\mathrm{McCall}$ et al., 2015). Control mice received a lentivirus containing mCherry alone under the PRSx8 promoter. Each animal received a $0.7-\mu \mathrm{l}$ infusion, and the infusion needle was left in place for $5 \mathrm{~min}$ after infusion to allow for viral diffusion. An optic fiber ferrule (ThorLabs) was implanted $0.5 \mathrm{~mm}$ dorsal to the viral injection site $(-5.4 \mathrm{AP} ;+1.2 \mathrm{ML} ;-3.5 \mathrm{DV})$ and permanently attached to the skull with screws and dental acrylic. Mice were singly housed after this surgery to prevent cage mates from damaging the headcap and given at least three weeks to recover and allow for full viral expression before testing.
Optogenetic stimulation

Mice were habituated to handling and connection of the optic patch cable to the implanted optic ferrule for at least one week before testing. The LC optogenetic stimulation was based on a previously published paradigm (McCall et al., 2015). Photostimulation was delivered to the LC for $30 \mathrm{~min}$ (5- $\mathrm{Hz}$ tonic stimulation, 10-ms light pulses, $473 \mathrm{~nm}$ ) in $3 \mathrm{~min}$ on/off bins in the home cage.

\section{Histology}

To assess correct targeting of the LC in mice used for optogenetic experiments, all animals were exposed to 5-Hz LC photostimulation for $15 \mathrm{~min}$ in the home cage, then anesthetized $90 \mathrm{~min}$ later with isoflurane and transcardially perfused with potassium PBS (KPBS), followed by $4 \%$ paraformaldehyde (PFA) in PBS. Brains were postfixed overnight by immersion in $4 \%$ PFA at $4^{\circ} \mathrm{C}$ and then transferred to $30 \%$ sucrose in KPBS for $48 \mathrm{~h}$ at $4^{\circ} \mathrm{C}$. Brains were flash frozen in isopentane on dry ice and embedded in Tissue Freezing Medium. Tissue was cryosectioned at $40 \mu \mathrm{m}$ for immunohistochemistry. Viral expression and correct optic fiber targeting were assessed by immunostaining for the mCherry tag using rabbit anti-DsRed primary antibody $(1: 1000)$ and goat antirabbit 568 secondary (1:500). Sections were co-stained for the noradrenergic marker tyrosine hydroxylase (TH) with chicken anti-TH (1:1000) and goat anti-chicken 488 secondary (1:500). In adjacent LC sections, activated LC neurons were detected with rabbit anti c-Fos primary antibody (1:5000) with goat anti-rabbit 488 secondary (1:500) and $\mathrm{TH}$-expressing cells were co-stained using chicken anti-TH $(1: 1000)$ with goat anti-chicken 568 secondary (1:500). After staining, all sections were mounted on slides and coverslipped with Fluoromount plus DAPI (Southern Biotech). Images were collected on a Leica DM6000B epifluorescent upright microscope at $10 \times$ or $20 \times$. Mice were excluded from analyses if they did not show viral expression in the $\mathrm{LC}$, correct optic fiber targeting, and increased c-Fos expression in the LC compared with the control animals of the same cohort. Antibodies are summarized in Table 1.

\section{Statistical analysis}

Data were found to be normally distributed using the D'AgostinoPearson test. Data were analyzed via unpaired $t$ test or two-way ANOVA with Sidak's correction for multiple comparisons, where appropriate. Significance was set at $p<0.05$, and two-tailed variants of tests were used throughout. Data are presented as mean \pm SEM. Calculations were performed and figures created using Prism Version 8 (GraphPad Software).

\section{Results}

Wheel running characteristics

Singly housed WT C57BL6/J mice were given unrestricted access to a running wheel in their home cage for $21 \mathrm{~d}$. Mice steadily increased their running distance over the first week, after which they ran $\sim 10-16 \mathrm{~km} / \mathrm{d}$, which is comparable to distances reported for $\mathrm{C} 57 \mathrm{BL} / 6 \mathrm{~J}$ mice in previous studies using similar running wheels (De Bono et al., 2006; Goh and Ladiges, 2015; Fig. 1). 
Female mice ran significantly more than males $\left(F_{(1,12)}=9.101, p=0.0107\right.$; Extended Data Fig. 1-1).

Exercise increases resilience to foot shock stress-induced anxiety-like behavior

At the end of the three weeks, half of the mice were subjected to a foot shock stressor. The following day, mice were put through a battery of behavioral tasks consisting of EZM, MB, and SPDB. Mice were then food-deprived overnight and tested in an NSF assay the next day before euthanasia and tissue collection (Fig. 2A). These behavioral assays were chosen to cover a range of both active (e.g., digging in $\mathrm{MB}$ and SPDB) and passive (e.g., freezing in SPDB, decreased exploration in EZM, longer latency to feed in NSF) anxiety-like behaviors displayed by mice, as well as to align with the behavioral assays previously used in our studies on the anxiolytic effects of exercise in rats (Sciolino et al., 2012, 2015). For the EZM, a two-way ANOVA showed a significant exercise $\times$ stress interaction $\left(F_{(1,25)}=\right.$ 5.718, $p=0.0246)$, and post hoc tests revealed that sedentary mice had a significant decrease in the time spent in the open arms of the EZM after stress $(p=0.0294)$, while stress had no effect on the exercise animals $(p=0.6810$; Fig. $2 B)$. No differences were seen in the $\mathrm{MB}$ test as a result of exercise $\left(F_{(1,25)}=2.265, p=0.1448\right)$ or stress $\left(F_{(1,25)}=\right.$ $0.06874, p=0.7953$; Fig. $2 C$ ).

In the SPDB assay, a two-way ANOVA showed a main effect of exercise $\left(F_{(1,19)}=9.133, p=0.007\right)$ and stress $\left(F_{(1,19)}=4.759, p=0.0419\right)$ on freezing behavior, with the stressed sedentary animals spending significantly more time freezing compared with non-stressed sedentary animals $(p=$ $0.021)$. The effects of stress were abrogated by exercise $(p=0.9489$; Fig. $2 D)$. There was a main effect of exercise on rearing behavior, showing that regardless of stress exposure $\left(F_{(1,19)}=\right.$ $0.09776, p=0.7579)$, exercise mice displayed more rearing bouts in the $\operatorname{SPDB}$ task $\left(F_{(1,19)}=16.24\right.$, $p=0.0007$; Fig. 2E). Exercise mice also had a slight, but significant increase in the number of shock probe touches from the electrified probe compared with sedentary mice $\left(F_{(1,19)}=6.004, p=0.0241\right)$, regardless of stress exposure $\left(F_{(1,19)}=0.01144, p=0.9160\right.$; Fig. $\left.2 F\right)$. There was no effect of exercise or stress on the amount of time mice spent grooming (exercise: $F_{(1,19)}=3.917, p=0.0625$; stress: $F_{(1,19)}=0.9914$, $p=0.3319$ ) or digging (exercise: $F_{(1,19)}=0.08843, p=0.7694$; stress: $\left.F_{(1,19)}=0.02293, p=0.8812\right)$ in the SPDB test (Fig. $\left.2 G, H\right)$.

In the NSF task, there was a main effect of exercise on the latency to eat the food in the novel environment $\left(F_{(1,25)}=\right.$ $78.94, p<0.0001)$ but no main effect of stress $\left(F_{(1,25)}=3.092\right.$, $p=0.0909)$. Post hoc testing revealed that stressed sedentary animals had a significantly longer latency to eat compared with non-stressed sedentary animals $(p=0.0243)$, with no effect of stress on the exercise animals ( $p=0.9825$; Fig. $2 I)$. As a control, the amount of food consumed by each mouse in $1 \mathrm{~h}$ immediately after the NSF test was recorded. There were no significant differences because of exercise $\left(F_{(1,25)}=2.371\right.$, $p=0.1361)$ or stress $\left(F_{(1,25)}=0.003919, p=0.9506\right.$; Fig. $\left.2 J\right)$. There were no differences between males and females in any behavioral measures (Extended Data Fig. 2-1). Together, these results demonstrate that chronic wheel running affords protection from the anxiogenic-like effects of foot shock stress.

\section{Exercise increases gal mRNA in the LC}

Several previous studies have shown that chronic voluntary exercise increases prepro-galanin mRNA in the LC of rats (Van Hoomissen et al., 2004; Holmes et al., 2006; Sciolino et al., 2012, 2015), but this change has never been examined in mice. We measured prepro-galanin mRNA in the LC of exercise and sedentary mice using in situ hybridization and found a robust and significant increase in galanin mRNA in exercise mice compared with their sedentary counterparts $\left(F_{(1,23)}=58.24, p<0.0001\right)$, with no difference according to stress exposure $\left(F_{(1,23)}=0.08014\right.$, $p=0.7796$; Fig. $3 A, B)$. Furthermore, we found a positive correlation between the average distance each mouse ran per day in the third week and the level of galanin mRNA in the LC $\left(r^{2}=0.4196\right.$, $p=0.0312$; Fig. $3 C)$, but not in week $1\left(r^{2}=0.08,222, p=0.3926\right)$ or week $2\left(r^{2}=0.2234, p=0.142\right.$; Fig. $\left.3 D, E\right)$. There were no significant differences between male and females in galanin mRNA level in the LC at baseline (sedentary) or after exercise (Extended 

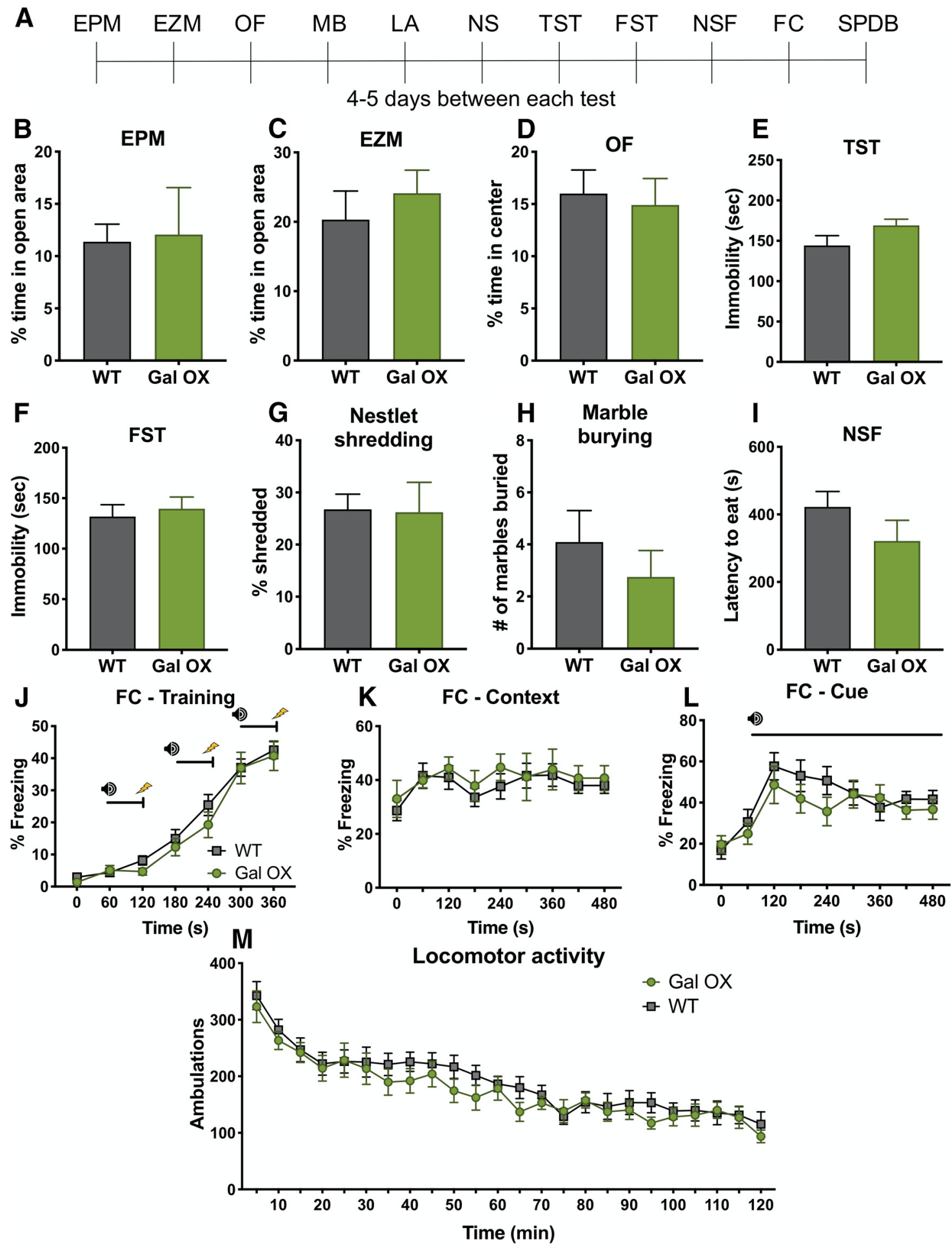

Figure 5. Gal $0 \mathrm{X}$ mice display normal behavior at baseline. A battery of behavioral tests was conducted on Gal OX mice compared with their WT littermates. A, Timeline showing order of tests. $\boldsymbol{B}$, EPM. C, EZM. D, OF. $\boldsymbol{E}$, TST, tail suspension test. $\boldsymbol{F}$, FST. G, NS, nestlet shredding. $\boldsymbol{H}, \mathbf{M B}$. $\boldsymbol{I}$, NSF. J-L, FC, fear conditioning. $\boldsymbol{M}$, LA, locomotor activity. SPDB. Gal OX mice were normal in all measures; $n=8-11$ mice per group, mixed males and females (for breakdown by sex, see Extended Data Fig. 5-1). Error bars show SEM.

Data Fig. 3-1). These results indicate that elevation of galanin expression in the LC occurs as a result of chronic physical activity in mice, similar to what is observed in rats.

Galanin mRNA levels in the LC correlate with exerciseinduced stress resilience

To further determine the relationship between galanin abundance in the LC and stress resilience, we examined whether the magnitude of galanin mRNA expression correlated with the exercise-induced stress resilience behavioral changes seen in the EZM, NSF, and SPDB assays. Strikingly, there was a non-significant trend toward a negative correlation between LC galanin expression and amount of time spent in the open arms of the EZM for non-stressed mice $\left(r^{2}=0.1036, p=0.2553\right)$, but a strong, significant positive correlation for stressed mice between these two measures $\left(r^{2}=0.7058, p=0.0152\right.$; Fig. $\left.4 A, B\right)$. There 
were significant negative correlations between galanin mRNA levels in the LC and latency to eat in the NSF assay for both nonstressed $\left(r^{2}=0.4873, p=0.0055\right)$ and stressed animals $\left(r^{2}=\right.$ $0.6279, p=0.0036$; Fig. $4 C, D)$. Finally, there was not a significant correlation between LC galanin mRNA levels and freezing during the SPDB assay for non-stressed mice $\left(r^{2}=0.2638, p=\right.$ $0.0876)$, but there was a significant negative correlation between these measures for stressed mice $\left(r^{2}=0.4981, p=0.0217\right.$; Fig. $4 E$, $F)$. For all three behaviors, the correlations with LC galanin mRNA levels were stronger (and in the case of EZM, opposite) in the stressed mice compared with non-stressed mice. Together, these data support the idea that LC-derived galanin is less important for anxiety-like behavior at baseline but becomes preferentially engaged by stress to confer resilience.

\section{Gal OX mice show normal baseline behavior}

Gal OX mice are reported to have normal performance in several canonical tests for anxiety-like behavior, including the EPM and OF test, but are resistant to yohimbine-induced anxiety-like behavior in a light-dark exploration task (Holmes et al., 2002). To confirm and expand on previous baseline behavioral studies conducted with the Gal OX mice, we conducted an extensive battery of anxiety-, depression-, learning-, and motor-related behavioral tasks (Fig. 5A). We observed no differences between Gal OX and littermate WT control mice in canonical tests of anxietylike behavior $\left(\mathrm{EPM}, t_{(17)}=0.1641, p=0.8717\right.$; zero maze, $t_{(17)}=$ $0.6739, p=0.5095$; OF, $\left.t_{(17)}=0.3211, p=0.7521\right)$ or depressivelike behavior (tail suspension test, $t_{(17)}=1.578, p=0.1331$; FST, $t_{(17)}=0.4564, p=0.6539 ;$ Fig. $\left.5 B-F\right)$. They showed no difference from WT littermates in compulsive behaviors during the nestlet shredding task $\left(t_{(7)}=0.07,861, p=0.9395\right)$ or MB task $\left(t_{(17)}=\right.$ $0.8051, p=0.4319$; Fig. 5G,H). Additionally, Gal OX behavior was comparable to WT in the NSF task $\left(t_{(17)}=1.355, p=0.1933\right.$; Fig. 5I). Gal OX mice exhibited normal cognitive responses in contextual $\left(F_{(1,17)}=0.2773, p=0.6053\right)$ and cued fear conditioning $\left(F_{(1,17)}=0.5667, p=0.4619\right.$; Fig. $\left.5 J-L\right)$. The locomotor activity of Gal OX mice was normal $\left(F_{(1,17)}=0.6486, p=0.4317\right.$; Fig. $5 M)$. In the SPDB task, Gal OX mice were normal in most behaviors, including digging $\left(t_{(12)}=0.7124, p=0.4899\right)$, freezing $\left(t_{(12)}\right.$ $=0.7015, p=0.4964)$, rearing $\left(t_{(12)}=0.4402, p=0.6676\right)$, and a number of probe touches $\left(t_{(12)}=0.6455, p=0.5308\right.$; Fig. $\left.6 A-D\right)$. The only exception was that Gal OX mice spent significantly less time grooming during the task than their WT counterparts $\left(t_{(12)}\right.$ $=3.152, p=0.0084 ;$ Fig. $6 E)$. There were no differences between males and females in any behavioral measures (Extended Data Figs. 5-1, 6-1).

\section{Gal OX mice are resistant to the behavioral effects of foot shock stress}

Although chronic wheel running increased galanin expression in the LC, exercise has pleiotropic effects on brain neurochemistry. To determine whether we could recapitulate the exerciseinduced stress resilience effect with chronically elevated noradrenergic galanin expression alone, we tested the response of Gal OX mice to the same foot shock stressor used in the exercise paradigm (Fig. 7A). We simplified the paradigm to include only the EZM because it revealed the most profound relationship between LC galanin expression and stress resilience in the exercise experiment (Figs. 2, 4), and activation of the LC vigorously and consistently increases anxiety-like behavior in this assay (McCall et al., 2015).

When tested in the EZM $24 \mathrm{~h}$ after foot shock, there was a main effect of genotype on the amount of time spent in the open arms

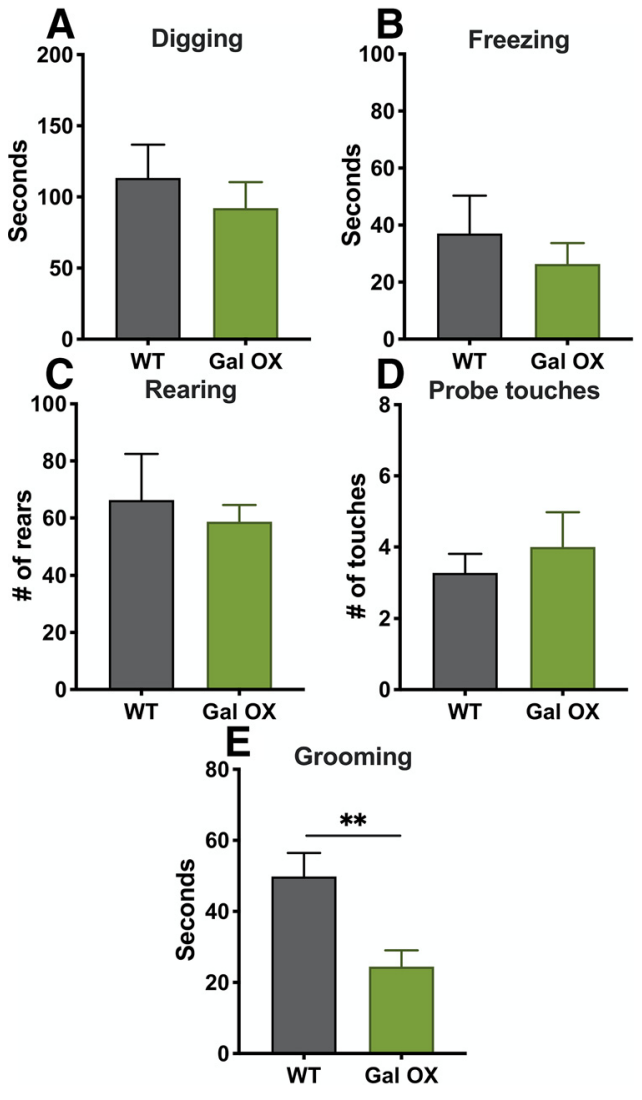

Figure 6. Gal OX mice display decreased grooming in the SPDB task. Gal OX mice were normal in all measures in the SPDB assay, including time spent digging $(\boldsymbol{A})$, freezing $(\boldsymbol{B})$, number of rears $(\boldsymbol{C})$, and probe touches $(\boldsymbol{D})$. However, they spent significantly more time grooming than WT controls $(\boldsymbol{E}) ; n=7$ mice per group, mixed males and females (for breakdown by sex, see Extended Data Fig. 6-1). Error bars show SEM; ${ }^{* *} p<0.01$.

$\left(F_{(1,33)}=11.81, p=0.0016\right)$. WT mice spent significantly less time in the open arms of the EZM $24 \mathrm{~h}$ after stressor exposure compared with non-stressed WT mice $(p=0.0191)$. However, Gal OX mice did not show this behavioral change after stress ( $p=0.9938$; Fig. $7 B$ ).

We conducted two control experiments to verify that galanin overexpression did not change the physiological responses to foot shock. First, we measured the amount of freezing during the administration of foot shocks and found no differences between WT and Gal OX mice $\left(F_{(1,10)}=0.01299, p=0.9115\right.$; Fig. $\left.7 C\right)$. Next, we measured foot shock-induced increases in plasma CORT levels and found a significant effect of stress $\left(F_{(1,23)}=\right.$ $17.12, p=0.0004)$, but no effect of genotype $\left(F_{(1,23)}=0.004147\right.$, $p=0.9492$ ), indicating that Gal OX mice have a normal CORT response to the foot shock stress itself and the neuroendocrine stress axis is functional in these mice (Fig. 7D). There were no differences between males and females (Extended Data Fig. 7-1). These results demonstrate that while Gal OX mice are initially affected by foot shock in the same way as their WT littermates, they are resistant to stress-induced behavioral changes $24 \mathrm{~h}$ later.

\section{Gal OX mice are resistant to the anxiogenic effects of acute optogenetic LC activation}

Foot shock stress engages many brain regions in addition to the LC. To more selectively target activation of the noradrenergic system, we used optogenetics to stimulate the LC immediately before EZM testing (Fig. 8A). The stimulation and behavioral protocols used here were based on a previously published paradigm of optogenetic LC activation-induced anxiety-like 
A

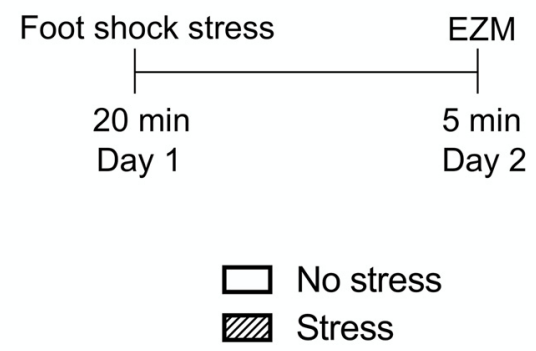

C
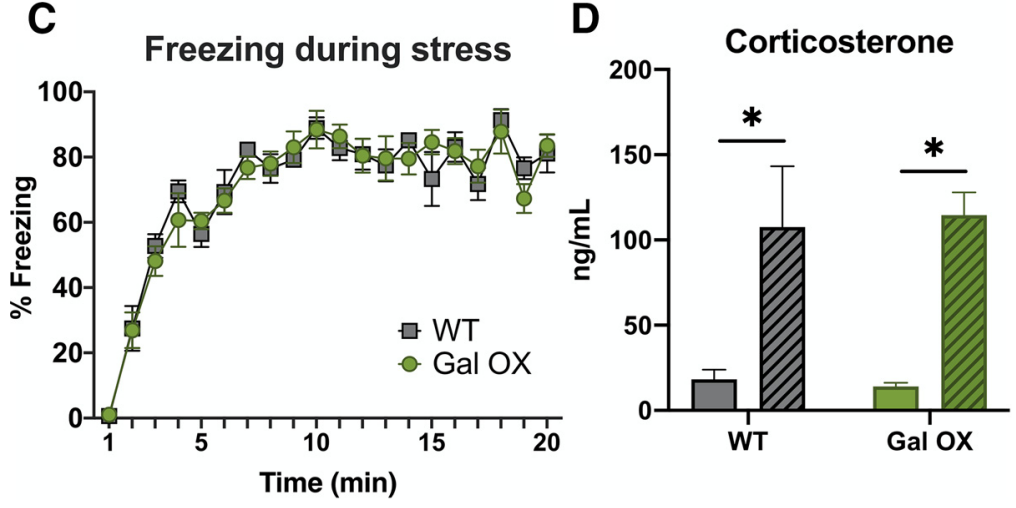

Figure 7. Gal OX mice are resistant to the anxiogenic effects of foot shock stress. Gal OX mice and WT littermate controls (WT) received 20 min of foot shock (Stress) or no foot shock (No stress) and were tested in the EZM $24 \mathrm{~h}$ later. A separate group of mice received foot shock or no foot shock, and blood was collected immediately afterward for CORT measurements. $\boldsymbol{A}$, Foot shock stress paradigm timeline. WT, but not Gal OX mice, showed a significant decrease in time spent in the open arms of the EZM $24 \mathrm{~h}$ after foot shock stress $(\boldsymbol{B})$. WT and Gal OX mice showed similar freezing behavior during the foot shock stress $(\boldsymbol{C})$ and similar increases in plasma CORT immediately following the foot shock stress $(\boldsymbol{D}) ; n=5-7$ mice per group for CORT analysis; $n=8-10$ mice per group for behavior, mixed males and females (for breakdown by sex, see Extended Data Fig. 7-1). Error bars show SEM; ${ }^{*} p<0.05$.

behavior (McCall et al., 2015). Mice received intra-LC infusion of virus expressing either ChR2-mCherry or mCherry alone. Viral expression and optic ferrule placement were confirmed in all animals by histology (Fig. $8 B$ ), and successful activation of the LC was confirmed via an increase in c-Fos expression $\left(t_{(8)}=\right.$ 2.798, $p=0.0233$; Fig. $8 C$ ). No differences in $c$-Fos expression after optogenetic stimulation were observed between genotypes. There were significant effects of both genotype $\left(F_{(1,32)}=13.18\right.$, $p=0.001)$ and virus $\left(F_{(1,32)}=8.569, p=0.0062\right)$ on the amount of time mice spent in the open arms of the zero maze, with post hoc testing showing that WT ChR2 mice spent significantly less time in the open arms compared with WT mCherry mice ( $p=$ 0.0234 ), while there was no difference between Gal OX mice that received the ChR2 and the mCherry virus $(p=0.2809$; Fig. $8 D)$. There were no differences between males and females (Extended Data Fig. 8-1). These results demonstrate that the Gal OX mice are resistant to LC stimulation-induced anxiety-like behavior.

\section{Discussion}

Although many studies have suggested a role for LC-derived galanin in stress resilience, most examined a single species (rat) and lacked direct evidence for the noradrenergic system as the functional source of the neuropeptide. To our knowledge, the present results are the first to demonstrate that (1) chronic exercise simultaneously increases both stress resilience and galanin expression in the LC of mice, and (2) increasing galanin in noradrenergic neurons ameliorates anxiogenic-like responses to stress and optogenetic LC stimulation.

We found that the level of galanin expression correlated with running distance in the third week, indicating that the relationship between physical activity and galanin abundance increases in a "dose-dependent" manner, as has been shown in rats (Holmes et al., 2006; Sciolino et al., 2012). Furthermore, we discovered that galanin mRNA expression in the LC correlated with exerciseinduced resilience in a stress-dependent manner. Stressed animals showed stronger (and in the case of EZM, opposite) correlations across all behavioral measures with galanin expression levels in the LC compared with non-stressed mice. In general, exercise had little effect on baseline behavior but ameliorated the anxiogenic effects of foot shock stress, similar to what we have reported in rats (Sciolino et al., 2015). However, we did observe that wheel running increased exploratory drive in behavioral paradigms that were not modulated by stress, such as rearing and probe touches in the SPDB. The results from our chronic voluntary wheel running experiment are consistent with other previous studies that showed enhanced stress resilience after chronic increases in physical activity in rodents (Sciolino et al., 2012; Kingston et al., 2018; Mul et al., 2018; Tanner et al., 2019). Female mice in our study consistently ran farther than male mice, as has been reported previously (De Bono et al., 2006; Bartling et al., 2017), but no other sex differences were observed. Our results support the idea that LC-derived galanin is less important for anxiety-like behavior at baseline but becomes preferentially engaged by stress to confer resilience.

Wheel running has wide-ranging effects on a variety of molecular and structural changes in the brain that may ameliorate the negative affective states induced by stress, including hippocampal neurogenesis and brain-derived neurotrophic factor ( $\mathrm{Li}$ et al., 2008; Liu and Nusslock, 2018), so it is possible that the alterations in the galanin system as a result of exercise work in concert with other systems in the brain to lead to an increase in stress resilience. To determine whether increasing galanin in noradrenergic neurons, alone, could recapitulate the anxiolytic effects of exercise, we turned to Gal OX mice. Similar to chronic exercise, Gal OX mice showed minimal behavioral differences from their WT littermates at baseline, consistent with much of the previous research suggesting that galaninergic effects are primarily evoked under conditions of stress that elicit high levels of neuronal activity. Galanin, like other neuropeptides, is stored in large dense core vesicles that require high frequency neuronal firing, such as those evoked in LC neurons by stress, to induce release (Lang et al., 2015). Gal OX mice did display decreased grooming in the SPDB assay. Because stress can elicit increased grooming behaviors in mice (Kalueff and Tuohimaa, 2004), decreased grooming could be indicative of increased resilience in 
the face of a stressful environment like the shockprobe task. Gal OX mice had a typical CORT response to foot shock, indicating that their neuroendocrine stress response was functioning normally, and customary freezing behavior during the stress itself. However, the decrease in open arm time in the EZM evident $24 \mathrm{~h}$ after foot shock observed in WT animals were completely abolished in Gal OX mice, suggesting that noradrenergic galanin promotes stress resilience.

While foot shock is a powerful activator of LC neurons, this stressor engages many other nodes of the stress response circuitry (Kim et al., 2016; Lecca et al., 2016). To isolate LC-induced anxiogenesis, we used LC-specific optogenetic stimulation immediately before testing in the EZM. The optogenetic parameters we employed were based on electrophysiological recordings of LC activity in response to stress and previously reported to induce anxiety-like behavior in the EZM. Importantly, the effect of optogenetic stimulation was blocked with $\beta$-adrenergic receptor antagonism, demonstrating that increased noradrenergic transmission was responsible for the anxiety-like behavior (McCall et al., 2015). Similar to the foot shock response, Gal OX mice did not display the anxiety-like behavior shown by their WT littermates. The fact that the Gal OX mice are resistant to this behavioral change suggests that increased noradrenergic galanin can dampen the stressrelated behavioral effects of increased LC activity.

We consider two main mechanisms by which chronically elevated galanin in the LC leads to increased stress resilience: (1) acute neuromodulatory actions of excess galanin being released during the stressor and acting somatodendritically to inhibit the LC itself or in downstream regions involved in mediating stress-induced behaviors, or (2) long-term neurotrophic changes in downstream brain regions mediated by chronically high levels of galanin signaling that confer anxiolysis. All three galanin receptors (GalR1-3) are G protein-coupled receptors that signal through inhibitory $G_{i / o}$ pathways, but GalR2 can also signal through $\mathrm{G}_{\mathrm{q} / 11}$, giving it a more complicated role in downstream signal processing (Lang et al., 2015). GalR2 is thought to regulate the long-term trophic actions of galanin, whereas GalR1 and GalR3 seem to be more important for the acute inhibitory neuromodulation by galanin (Hobson et al., 2008; Holmes, 2014; Weinshenker and Holmes, 2015). We favor the chronic neurotrophic mechanism to explain our present and previous findings. In our previous study (Sciolino et al., 2015), we found that either chronic exercise or chronic ICV galanin protected against stress-induced anxiogenic behavior and dendritic spine loss in the medial prefrontal cortex (mPFC) of rats. Importantly, chronic but not acute infusion of a galanin antagonist blocked the beneficial effects of exercise on neuroplasticity and behavior, supporting the idea that the stress resilience is caused by chronic elevated galanin leading
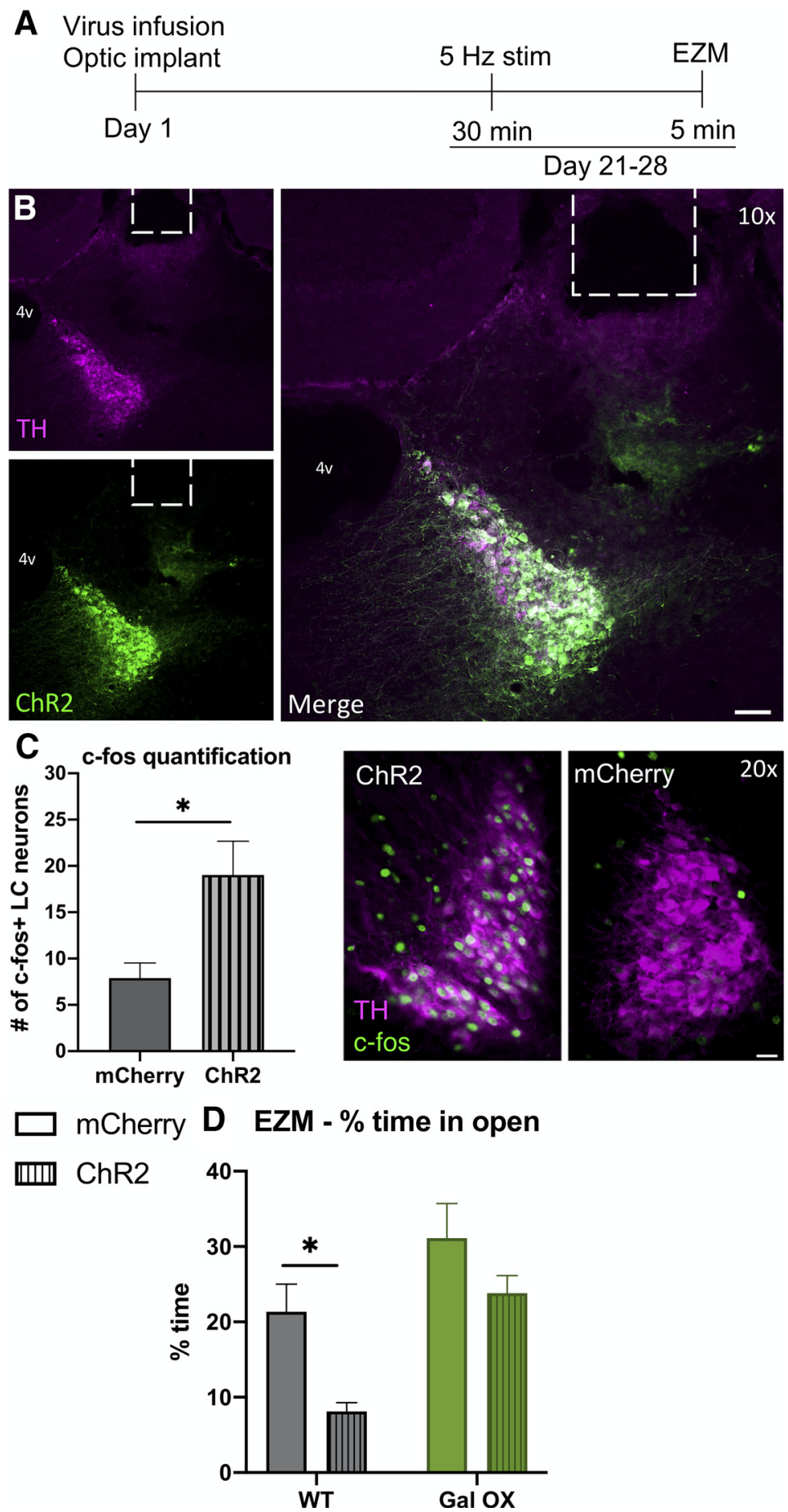

Figure 8. Gal OX mice are resistant to the anxiogenic effects of optogenetic $\mathrm{LC}$ activation. Gal $\mathrm{OX}$ and WT littermate controls (WT) were given 30 min of optogenetic LC stimulation and then tested in the EZM. At least one week later, all mice were given 15 min of optogenetic $\mathrm{LC}$ stimulation, and brains were collected for c-fos immunohistochemistry $90 \mathrm{~min}$ later. $\boldsymbol{A}$, Optogenetic surgery and behavior timeline. $\boldsymbol{B}$, Representative images of ChR2 viral expression (green) and TH (magenta) overlap in the $\mathrm{LC}$ and optic fiber ferrule placement (scale bar, $50 \mu \mathrm{m} ; 4 \mathrm{v}$, fourth ventricle). C, Optogenetic stimulation of the LC leads to increased c-fos expression in LC neurons with the ChR2 virus, but not in mice with the control mCherry virus. No differences in c-fos expression between genotypes were seen, so data shown are collapsed across genotype (TH, magenta; c-fos, green; scale bar, $20 \mu \mathrm{m}$ ). Optogenetic stimulation causes WT-ChR2 mice to spend less time in the open arms of the EZM compared with WT- mCherry mice but does not impact the behavior of Gal OX mice (D); $n=8-10$ mice per group, mixed males and females (for breakdown by sex, see Extended Data Fig. 8-1). Error bars show SEM; ${ }^{*} p<0.05$. 
to long-term neurotrophic adaptation, not acute increases in galanin's neuromodulatory actions. These data suggest that a similar neurotrophic mechanism likely underlies our present results.

There are several caveats associated with the Gal OX mice used in this study. The first is that the overexpression of galanin is not entirely noradrenergic-specific; they have some ectopic expression of galanin in non-noradrenergic neurons in the piriform and entorhinal cortex (Steiner et al., 2001). Additionally, galanin is not only overexpressed in noradrenergic nuclei that normally express galanin, such as the LC, but all noradrenergic and adrenergic cell groups, leading to high levels of galanin in neurons that do not contain it endogenously. Some of these (e.g., the Hoxb1 cluster in the medulla and pons outside of the LC; Chen et al., 2019) have been implicated in stress and anxiety-like responses. Thus, we cannot definitively ascribe the effects we obtained using the Gal OX mice specifically to the LC-derived galanin. Despite this, because of the LC's well-defined role in regulating the stress response, the broad projections of the LC to other stress-sensitive brain regions, the phenotypic similarities between the Gal OX mice and exercise mice that have elevated galanin exclusively in the LC, and our LC-specific optogenetic results, it seems likely that chronically elevated galanin in the LC contributes to enhanced stress resilience.

Combined with the existing literature, the results from the present study demonstrate that noradrenergic galanin promotes stress resilience across species, and that its enrichment can come from either an environmental (exercise) or genetic (transgenic overexpression) source. Future studies will further dissect how galaninergic transmission from noradrenergic sources underlie its anxiolytic properties. The critical galanin receptor (GalR1-3), the mode of signaling (acute neuromodulatory vs chronic neurotrophic), and the downstream targets in the stress response network (e.g., PFC, amygdala) remain to be identified. The galanin system remains a promising target for both pharmacotherapies and non-drug treatments for affective disorders.

\section{References}

Ashdown-Franks G, Firth J, Carney R, Carvalho AF, Hallgren M, Koyanagi A, Rosenbaum S, Schuch FB, Smith L, Solmi M, Vancampfort D, Stubbs B (2020) Exercise as medicine for mental and substance use disorders: a meta-review of the benefits for neuropsychiatric and cognitive outcomes. Sports Med 50:151-170.

Barde S, Ruegg J, Prud'homme J, Ekstrom TJ, Palkovits M, Turecki G, Bagdy G, Ihnatko R, Theodorsson E, Juhasz G, Diaz-Heijtz R, Mechawar N, Hokfelt T (2016) Alterations in the neuropeptide galanin system in major depressive disorder involve levels of transcripts, methylation, and peptide. Proc Natl Acad Sci USA 113:E8472-E8481.

Bartling B, Al-Robaiy S, Lehnich H, Binder L, Hiebl B, Simm A (2017) Sexrelated differences in the wheel-running activity of mice decline with increasing age. Exp Gerontol 87:139-147.

Bissette G, Klimek V, Pan J, Stockmeier C, Ordway G (2003) Elevated concentrations of CRF in the locus coeruleus of depressed subjects. Neuropsychopharmacology 28:1328-1335.

Carter ME, Yizhar O, Chikahisa S, Nguyen H, Adamantidis A, Nishino S, Deisseroth K, de Lecea L (2010) Tuning arousal with optogenetic modulation of locus coeruleus neurons. Nat Neurosci 13:1526-1533.

Chan-Palay V, Jentsch B, Lang W, Höchli M, Asan E (1990) Distribution of neuropeptide Y, C-terminal flanking peptide of NPY and galanin coexistence with catecholamine in the locus coeruleus of normal human, Alzheimer's dementia and Parkinson's disease brains. Dement Geriatr Cogn Disord 1:18-31.

Chekroud SR, Gueorguieva R, Zheutlin AB, Paulus M, Krumholz HM, Krystal JH, Chekroud AM (2018) Association between physical exercise and mental health in 1.2 million individuals in the USA between 2011 and 2015: a cross-sectional study. Lancet Psychiatry 5:739-746.
Chen YW, Das M, Oyarzabal EA, Cheng Q, Plummer NW, Smith KG, Jones GK, Malawsky D, Yakel JL, Shih YI, Jensen P (2019) Genetic identification of a population of noradrenergic neurons implicated in attenuation of stress-related responses. Mol Psychiatry 24:710-725.

Cooney GM, Dwan K, Greig CA, Lawlor DA, Rimer J, Waugh FR, McMurdo M, Mead GE (2013) Exercise for depression. Cochrane Database Syst Rev. Advance online publication. Retrieved Sept 12, 2013. doi: 10.1002/ 14651858.CD004366.pub6.

De Bono JP, Adlam D, Paterson DJ, Channon KM (2006) Novel quantitative phenotypes of exercise training in mouse models. Am J Physiol Regul Integr Comp Physiol 290:R926-R934.

Ehnvall A, Sjögren M, Zachrisson OCG, Agren H (2003) Lifetime burden of mood swings and activation of brain norepinephrine turnover in patients with treatment-refractory depressive illness. J Affect Disord 74:185-189.

Epps SA, Kahn AB, Holmes PV, Boss-Williams KA, Weiss JM, Weinshenker D (2013) Antidepressant and anticonvulsant effects of exercise in a rat model of epilepsy and depression comorbidity. Epilepsy Behav 29:47-52.

Fang P, He B, Shi M, Zhu Y, Bo P, Zhang Z (2015) Crosstalk between exercise and galanin system alleviates insulin resistance. Neurosci Biobehav Rev 59:141-146.

Goh J, Ladiges W (2015) Voluntary wheel running in mice. Curr Protoc Mouse Biol 5:283-290.

Harvey SB, Øverland S, Hatch SL, Wessely S, Mykletun A, Hotopf M (2018) Exercise and the prevention of depression: results of the HUNT cohort study. Am J Psychiatry 175:28-36.

Herring MP, O'Connor PJ, Dishman RK (2010) The effect of exercise training on anxiety symptoms among patients. Arch Intern Med 170:321-331.

Hobson SA, Bacon A, Elliot-Hunt CR, Holmes FE, Kerr NC, Pope R, Vanderplank P, Wynick D (2008) Galanin acts as a trophic factor to the central and peripheral nervous systems. Cell Mol Life Sci 65:1806-1812.

Holets VR, Hökfelt T, Rökaeus A, Terenius L, Goldstein M (1988) Locus coeruleus neurons in the rat containing neuropeptide $\mathrm{Y}$, tyrosine hydroxylase or galanin and their efferent projections to the spinal cord, cerebral cortex and hypothalamus. Neuroscience 24:893-906.

Holmes PV (2014) Trophic mechanisms for exercise-induced stress resilience: potential role of interactions between BDNF and galanin. Front Psychiatry 5:90.

Holmes A, Yang RJ, Crawley JN (2002) Evaluation of an anxiety-related phenotype in galanin overexpressing transgenic mice. J Mol Neurosci 18:151-165.

Holmes PV, Yoo HS, Dishman RK (2006) Voluntary exercise and clomipramine treatment elevate prepro-galanin mRNA levels in the locus coeruleus in rats. Neurosci Lett 408:1-4.

Hwang DY, Carlezon WA, Isacson O, Kim KS (2001) A high-efficiency synthetic expression selectively promoter that drives transgene in noradrenergic neurons. Hum Gene Ther 12:1731-1740.

James SL, Abate D, Abate KH, Abay SM, Abbafati C, Abbasi N, Abbastabar H, Abd-Allah F, Abdela J, Abdelalim A, Abdollahpour I, Abdulkader RS, Abebe Z, Abera SF, Abil OZ, Abraha HN, Abu-Raddad LJ, Abu-Rmeileh NME, Accrombessi MMK, Acharya D, et al. (2018) Global, regional, and national incidence, prevalence, and years lived with disability for 354 diseases and injuries for 195 countries and territories, 1990-2017: a systematic analysis for the Global Burden of Disease Study 2017. Lancet 392:1789-1858.

Kalueff AV, Tuohimaa P (2004) Grooming analysis algorithm for neurobehavioural stress research. Brain Res Brain Res Protoc 13:151-158.

Kim Y, Perova Z, Mirrione MM, Pradhan K, Henn FA, Shea S, Osten P, Li B (2016) Whole-brain mapping of neuronal activity in the learned helplessness model of depression. Front Neural Circuits 10:3.

Kingston RC, Smith M, Lacey T, Edwards M, Best JN, Markham CM (2018) Voluntary exercise increases resilience to social defeat stress in Syrian hamsters. Physiol Behav 188:194-198.

Kofler B, Berger A, Santic R, Moritz K, Almer D, Tuechler C, Lang R, Emberger M, Klausegger A, Sperl W, Bauer JW (2004) Expression of neuropeptide galanin and galanin receptors in human skin. J Invest Dermatol 122:1050-1053.

Lang R, Gundlach AL, Holmes FE, Hobson SA, Wynick D, Hökfelt T, Kofler B (2015) Physiology, signaling, and pharmacology of galanin peptides and receptors: three decades of emerging diversity. Pharmacol Rev 67:118-175.

Le Maître E, Barde SS, Palkovits M, Diaz-Heijtz R, Hökfelt TGM (2013) Distinct features of neurotransmitter systems in the human brain with 
focus on the galanin system in locus coeruleus and dorsal raphe. Proc Natl Acad Sci USA 110:E536-E545.

Lecca S, Pelosi A, Tchenio A, Moutkine I, Lujan R, Hervé D, Mameli M (2016) Rescue of GABAB and GIRK function in the lateral habenula by protein phosphatase $2 \mathrm{~A}$ inhibition ameliorates depression-like phenotypes in mice. Nat Med 22:254-261.

Li Y, Luikart BW, Birnbaum S, Chen J, Kwon CH, Kernie SG, Bassel-Duby R, Parada LF (2008) TrkB regulates hippocampal neurogenesis and governs sensitivity to antidepressive treatment. Neuron 59:399-412.

Liu PZ, Nusslock R (2018) Exercise-mediated neurogenesis in the hippocampus via BDNF. Front Neurosci 12:52.

McCall JG, Al-Hasani R, Siuda ER, Hong DY, Norris AJ, Ford CP, Bruchas MR (2015) CRH engagement of the locus coeruleus noradrenergic system mediates stress-induced anxiety. Neuron 87:605-620.

Melander T, Hökfelt T, Rökaeus A, Cuello A, Oertel W, Verhofstad A, Goldstein M (1986) Coexistence of galanin-like immunoreactivity with catecholamines, 5-hydroxytryptamine, GABA and neuropeptides in the rat CNS. J Neurosci 6:3640-3654.

Mitsukawa K, Lu X, Bartfai T (2008) Galanin, galanin receptors and drug targets. Cell Mol Life Sci 65:1796-1805.

Mul JD, Soto M, Cahill ME, Ryan RE, Takahashi H, So K, Zheng J, Croote DE, Hirshman MF, la Fleur SE, Nestler EJ, Goodyear LJ (2018) Voluntary wheel running promotes resilience to chronic social defeat stress in mice: a role for nucleus accumbens $\Delta$ FosB. Neuropsychopharmacology 43:1934-1942.

Naegeli C, Zeffiro T, Piccirelli M, Jaillard A, Weilenmann A, Hassanpour K, Schick M, Rufer M, Orr SP, Mueller-Pfeiffer C (2018) Locus coeruleus activity mediates hyperresponsiveness in posttraumatic stress disorder. Biol Psychiatry 83:254-262.

Nestler EJ, Barrot M, DiLeone RJ, Eisch AJ, Gold SJ, Monteggia LM (2002) Neurobiology of depression. Neuron 34:13-25.

O’Neal HA, Van Hoomissen JD, Holmes PV, Dishman RK (2001) Preprogalanin messenger RNA levels are increased in rat locus coeruleus after treadmill exercise training. Neurosci Lett 299:69-72.

Ordway GA, Widdowson PS, Smith KS, Halaris A (1994) Agonist binding to alpha 2-adrenoceptors is elevated in the locus coeruleus from victims of suicide. J Neurochem 63:617-624.

Pérez SE, Wynick D, Steiner RA, Mufson EJ (2001) Distribution of galaninergic immunoreactivity in the brain of the mouse. J Comp Neurol 434:158185.

Roy A, Pickar D, De Jong J, Karoum F, Linnoila M (1988) Norepinephrine and its metabolites in cerebrospinal fluid, plasma, and urine. Relationship to hypothalamic-pituitary-adrenal axis function in depression. Arch Gen Psychiatry 45:849-857.

Roy B, Wang Q, Palkovits M, Faludi G, Dwivedi Y (2017) Altered miRNA expression network in locus coeruleus of depressed suicide subjects. Sci Rep 7:4387.
Rush AJ, Trivedi MH, Wisniewski SR, Nierenberg AA, Stewart JW, Warden D, Niederehe G, Thase ME, Lavori PW, Lebowitz BD, McGrath PJ, Rosenbaum JF, Sackeim HA, Kupfer DJ, Luther J, Fava M (2006) Acute and longer-term outcomes in depressed outpatients requiring one or several treatment steps: a STAR ${ }^{\star}$ D report. Am J Psychiatry 163:1905-1917.

Sciolino NR, Dishman RK, Holmes PV (2012) Voluntary exercise offers anxiolytic potential and amplifies galanin gene expression in the locus coeruleus of the rat. Behav Brain Res 233:191-200.

Sciolino NR, Smith JM, Stranahan AM, Freeman KG, Edwards GL, Weinshenker D, Holmes PV (2015) Galanin mediates features of neural and behavioral stress resilience afforded by exercise. Neuropharmacology $89: 255-264$.

Skofitsch G, Jacobowitz D (1985) Immunohistochemical mapping of galanin-like neurons in the rat central nervous system. Peptides 6:509-546.

Steiner RA, Hohmann JG, Holmes A, Wrenn CC, Cadd G, Juréus A, Clifton DK, Luo M, Gutshall M, Ma SY, Mufson EJ, Crawley JN (2001) Galanin transgenic mice display cognitive and neurochemical deficits characteristic of Alzheimer's disease. Proc Natl Acad Sci USA 98:4184-4189.

Tanner MK, Fallon IP, Baratta MV, Greenwood BN (2019) Voluntary exercise enables stress resistance in females. Behav Brain Res 369:111923.

Tatemoto K, Rökaeus A, Jörnvall H, McDonald T, Mutt V (1983) Galanin - a novel biologically active peptide from porcine intestine. FEBS Lett 164:124-128.

Tillage RP, Sciolino NR, Plummer NW, Lustberg D, Liles LC, Hsiang M, Powell JM, Smith KG, Jensen P, Weinshenker D (2020) Elimination of galanin synthesis in noradrenergic neurons reduces galanin in select brain areas and promotes active coping behaviors. Brain Struct Funct 225:785-803.

Valentino RJ, Van Bockstaele E (2008) Convergent regulation of locus coeruleus activity as an adaptive response to stress. Eur J Pharmacol 583:194203.

Van Hoomissen JD, Holmes PV, Zellner AS, Poudevigne A, Dishman RK (2004) Effects of beta-adrenoreceptor blockade during chronic exercise on contextual fear conditioning and mRNA for galanin and brainderived neurotrophic factor. Behav Neurosci 118:1378-1390.

Weinshenker D, Holmes PV (2015) Regulation of neurological and neuropsychiatric phenotypes by locus coeruleus-derived galanin. Brain Res 1641:320-337.

Whitworth JW, Ciccolo JT (2016) Exercise and post-traumatic stress disorder in military veterans: a systematic review. Mil Med 181:953-960.

Wong ML, Kling MA, Munson PJ, Listwak S, Licinio J, Prolo P, Karp B, McCutcheon IE, Geracioti TD, DeBellis MD, Rice KC, Goldstein DS, Veldhuis JD, Chrousos GP, Oldfield EH, McCann SM, Gold PW (2000) Pronounced and sustained central hypernoradrenergic function in major depression with melancholic features- Relation to hypercortisolism and corticotropin-releasing hormone. Proc Natl Acad Sci USA 97:325-330. 